\title{
RESPONSE OF VEGETATION ON GRAVEL BARS TO MANAGEMENT MEASURES AND FLOODS: CASE STUDY FROM THE CZECH REPUBLIC
}

\author{
RENATA EREMIÁŠOVÁ, HANA SKOKANOVÁ*
}

Silva Tarouca Research Institute for Landscape and Ornamental Gardening, Lidická 25/27, 60200 Brno, Czech Republic; email: hanka@skokan.net

${ }^{\star}$ Author for correspondence

\begin{abstract}
Eremiášová R., Skokanová H.: Response of vegetation on gravel bars to management measures and floods: case study from the Czech Republic. Ekológia (Bratislava), Vol. 33, No. 3, p. 274-285, 2014.

This article investigates response of vegetation on gravel bars to management measures and floods. The management measures consisted of the partial removal of gravel and vegetation cover, and were applied to six gravel bars on the Ostravice River, Czech Republic. Unexpected floods occurred in 2010, with the amplitude of 5- to 50-year repetition. Research of vegetation on the gravel bars consisted of vegetation survey before the management works; the monitoring of vegetation development over the following year and the verification of the relationships of species diversity, successional stages and the biotope conditions with the help of multivariate analysis (detrended correspondence analysis). Vegetation on the gravel bars was at different successional stages, and had higher diversity and vegetation cover before the management measures and floods. The multivariate analysis revealed a shift toward initial successional stages with high demand on moisture, temperature and light after both management measures and floods.
\end{abstract}

Key words: gravel bar, natural biotopes, vegetation succession, management measures, floods, Czech Republic.

\section{Introduction}

\section{Vegetation on gravel bars}

Gravel bars are a typical feature of gravel-bed rivers that are common in temperate piedmont and mountain-valley areas. Gravel-bed rivers are characterized by a set of fluvial styles, including straight, braided, wandering and meandering channels (Richards et al., 2002). Today, most gravel-bed rivers bear little resemblance to their highly dynamic natural state and belong to the most endangered biotopes in the world (Tockner et al., 2003). Natural biotopes that can be found at gravel bars are, according to the classification created for NATURA 2000 sites (Chytrý et al., 2001), unvegetated river gravel banks, river gravel banks with Calamagrostis pseudophragmites and willow scrub of river gravel banks. According to the Council 
Directive 92/43/EEC, on the conservation of natural habitats and wild fauna and flora, these biotopes are classified as significantly endangered, easily vulnerable and quickly disappearing throughout Europe.

Because of the dynamic environment with high kinetic energy and large amounts of transported material in the form of gravel and stone, vegetation on gravel bars cannot reach climax stage which is typical for other environments (Loučková, 2012).

The speed of vegetation succession on a gravel bar depends on its location, if it is a midchannel bar or a sidebar, on the supply of diasporas and on the load of branches or whole trunks of fast-growing trees, especially of Salix and Populus. Elevation is another important factor in the succession. Plants in low-lying areas are subject to low drought stress, but high disturbance, owing to frequent inundation, deposition of fines and bed-load movement. Periodic disturbance prevents competitive displacement of pioneer species. Higher up the bar, on freely draining gravels, particularly where particle size is large and there is little interstitial sediment, only relatively drought-tolerant species persist. In these areas, the gradual establishment of deep-rooting trees or nitrogen-fixing shrubs provides shade and litter and, together with the settlement of large woody debris, traps fine sediment, thereby aiding moisture retention and soil development, to establish other species (Gilvear, Willby, 2006). Another factor influencing succession is floods, namely their extent, frequency, duration and depth (Hupp, Osterkamp, 1985; Prach, 1994; Chuman et al., 2006; Gilvear, Willby, 2006). The floods largely inhibit already present individuals, and eliminate species that are not adapted to floods, in terms of lack of oxygen and mechanical destruction by transported material (Chuman et al., 2006).

The issues of vegetation succession on gravel bars have been researched e.g. on rivers in the north-eastern Himalaya in the work of Prach (1994), on rivers in the USA (Bliss, Cantlon, 1957; Mouw et al., 2013), Italy (Edwards et al., 1999; Gurnell et al., 2001; Tockner et al., 2003), Scotland (Gilvear, Willby, 2006), Slovakia (Jeník, 1955) or the Czech Republic (Kopecký, 1957; Blažková, 2003; Loučková, 2012). All the mentioned studies dealt with vegetation succession occurring after natural disturbances, especially floods, or studied interactions between vegetation and fluvial processes.

In the intensively used and populated floodplains, the overgrown gravel bars in the regulated channel represent a potential risk, namely during floods. The water management authority usually removes them and restores the original parameters of the flow profile. However, repeated elimination of sedimentation sources causes an increase in the water velocity and sheer stress, and the consequent higher erosion of the river bed. This leads to rapid water run-off from the area and also the destruction of unique biotopes bound to gravel bars. Thus it is necessary to find a balance between the protection of human settlements against floods and nature conservation. For this purpose, management measures reflecting both aspects were suggested for six gravel bars on the Ostravice River, Czech Republic, and were followed by monitoring their impact on vegetation succession on these bars.

This article investigates how vegetation on six gravel bars of the Ostravice River responded to the management measures of water management authority, which were carried out in 2009 and 2010, and were unexpectedly enhanced by floods that occurred in May and June, 2010. The emphasis is put on the species distribution and its relationship with environmental conditions in the early stage of succession. 


\section{Study area}

The study area Ostravice River is situated in north-eastern Moravia, Czech Republic (Fig. 1). It belongs to the network of NATURA 2000 sites, namely sites of community importance (Council directive 92/43/EHS on the conservation of natural habitats and wild fauna and flora). It covers $81.12 \mathrm{ha}$, includes the middle reach delimitated by the confluence of the Ostravice and Olešná rivers, in the village of Paskov in the north $(15.5 \mathrm{~km})$, and to the border of Protected Landscape Area Beskids in the south $(42.0 \mathrm{~km})$. The elevation ranges between 250 and $421 \mathrm{~m}$.

Flysch (sequence of sedimentary rocks such as sandstones and shale/claystones) is the main geological feature of the upper part of the river channel, and is easily erodible. As a consequence, the Ostravice, together with the majority of other rivers in the region, belongs to gravel-bed rivers and creates a typical Carpathian stream with a well-developed floodplain (Buček, Štykar, 2001; Weissmannová et al., 2004; Birklen et al., 2008). The floodplain is made up of Quaternary loess, sand and gravel. Fluvisols, plano-gleyic luvisols and cambisols are typical soil cover (Weissmannová et al., 2004). Natural vegetation belongs to the associations Pruno-Fraxinetum and Alnion glutionsae (Neuhäuslová et al., 2001); communities belonging to associations Phalaridion arundinacea and Salicion eleagnodaphnoides occur on the gravel bars (Moravec et al., 1995).

The Ostravice River is a major right tributary of the Odra River. Average inclination of the Ostravice is $9.6 \%$. It originates from two creeks that meet at the elevation $521 \mathrm{~m}$ in the Moravian-Silesian Beskids Mountains. The total length is $54.8 \mathrm{~km}$ and the catchment area is $826.8 \mathrm{~km}^{2}$. The average annual discharge at the confluence with the Odra River is $14.25 \mathrm{~m}^{3} / \mathrm{s}$. In Frýdek-Místek, which is a major town situated in the middle reach, the average annual discharge is $10.3 \mathrm{~m}^{3} / \mathrm{s}$ (Kalníková, 2009). In 1964-1969, a water reservoir was built in the upper reach between 45.7 and $52.0 \mathrm{~km}$. The retention capacity of the catchment is low; the discharge fluctuates strongly, with peaks in spring and summer. The discharge coefficient in the upper part of the catchment is high, relatively high in the middle part and medium in the lower part (Buček, Štykar, 2001).
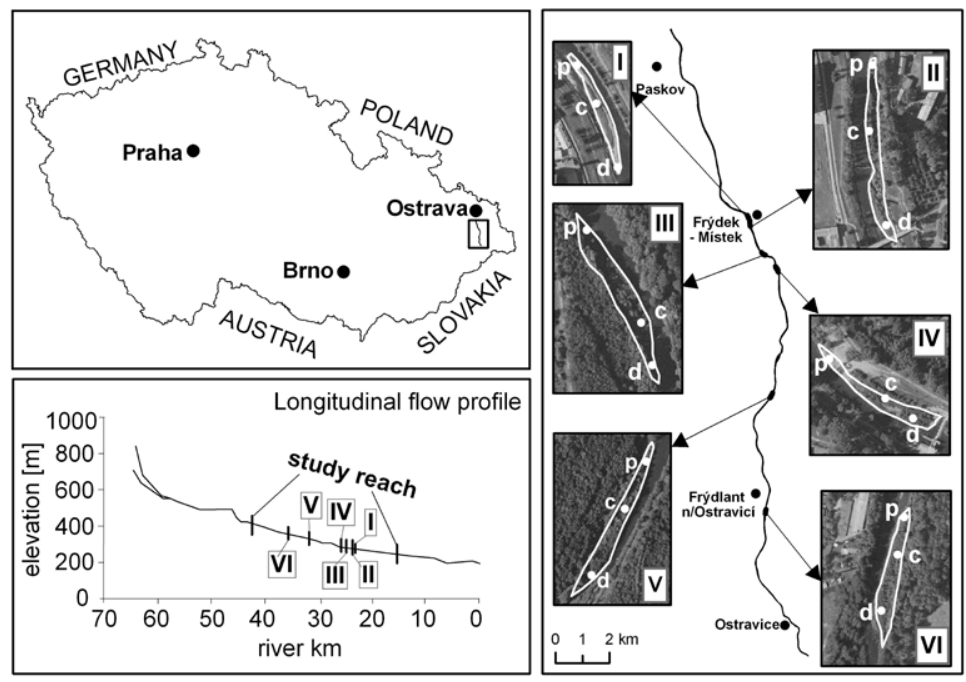

Fig. 1. Location of the Ostravice River study area, including longitudinal flow profile of the Ostravice with position of gravel bars (lower left) and location of permanent plots on the bars (right) ( $\mathrm{p}$ - proximal, $\mathrm{c}$ - central, $\mathrm{d}$ - distal part of the bar); the shape of the bars is from 2009 survey.

The Ostravice was channelized in the second half of the twentieth century. The channel banks have been riprapped extensively with large quarry stones, which partly define the border of the active channel (10-15 $\mathrm{m}$ in width), and partly separate from the river an outer up to $60 \mathrm{~m}$ broad part of an originally wide-braided channel. Lateral parts 
of the original channel were separated from the river artificially. Revetments and dykes prevent water from the river penetrating these overgrowing branches with pools (Hrádek, 2004). Despite river channelization, many gravel bars have developed in the channel. The bar development was greatly influenced by catastrophic floods in 1997, which restored some reaches of the river.

Six gravel bars in the Ostravice were chosen for water management. Heavily overgrown bars both outside and inside urban area that decreased the channel capacity were selected. All bars were point bars before the management works from 2009-2010. Their location is in Fig. 1.

\section{Management of gravel bars}

A management model of gravel bars was suggested for bars selected by the water management authority in the Ostravice reach, belonging to the NATURA 2000 sites, for the purposes of both flood protection and nature conservation. The management model aims to improve the flow capacity of the Ostravice channel, and is carried out when a gravel bar is largely overgrown by woody vegetation. It consists of several steps. The upper sediment layer of a bar will be partly removed and the bar surface will be modelled in such a way to remain undulating, and to offer variable ecological conditions, thus ensuring existence of biotopes typical for this type of biotopes. About $30-50 \%$ of removed sediments will remain in the channel (Birklen et al., 2008). Developed woody vegetation on the bars in urban areas will be cut down. When the majority of the bar is overgrown by woody vegetation, the bar will be removed repeatedly.

It should be emphasized that the suggested management is only valid for selected bars, while the remaining bars are removed completely from the channel when largely overgrown by woody vegetation, which is the common practice in the Czech Republic.

\section{Floods in May and June, 2010}

Floods were recorded predominantly in north-eastern Moravia at the end of May and beginning of June, 2010, as a result of two episodes of very intensive rain. The first occurred between 15th and 20th May, and the second between 30th May and 3rd June. Both episodes were caused by a low pressure area settling for a long period east of the Czech Republic (Sandev et al., 2011). The intensive rainfall was enhanced by the orographic effect of the windward side of the Moravian-Silesian Beskids Mountains.

May 2010 was, in general, very rich in precipitation; the monthly rainfall in Moravia reached $187 \mathrm{~mm}$, which was $243 \%$ of the 1961-1990 long-term average (Sandev et al., 2011). In the study area, the highest May rainfall ranged between 408 and $471 \mathrm{~mm}$ (the 1961-1990 long-term average ranges between 99 and $113 \mathrm{~mm}$ ). During the first episode at the end of May, the total rainfall in the study area, recorded at the selected stations of the Czech Hydro-meteorological Institute, was $313 \mathrm{~mm}$ (upper part of the study area), $263 \mathrm{~mm}$ (middle part) and $234 \mathrm{~mm}$ (lower part). The total rainfall from the second episode was much lower; the values reached only $82 \mathrm{~mm}$ in the upper part, $75 \mathrm{~mm}$ in the middle part and $87 \mathrm{~mm}$ in the lower part (Sandev et al., 2011). Owing to the high amount of precipitation in the first half of the May, the soil was highly saturated. This fact also affected the course of the floods considerably.

Only the first rain episode influenced floods in the study area significantly. The flood wave peaked on 17th May in the lower part (discharge $546 \mathrm{~m}^{3} / \mathrm{s}$, water level $498 \mathrm{~cm}$, which corresponds to a 20- to 50-year flood), and on 18th May in the upper part (discharge $129 \mathrm{~m}^{3} / \mathrm{s}$, water level $305 \mathrm{~cm}$, which corresponds to a 2- to 5-year flood) of the study area (Sandev et al., 2011). The discharges were affected strongly by a reservoir built in the upper reach which lessened the discharge. Sandev et al. (2011) calculated that without this reservoir, the culmination discharges would correspond to a 50- to 100-year flood in the lower part of the study area, and to a 10- to 20-year flood in the upper part.

The second rain episode was not so pronounced in the study area, and the discharge values were not as high as in the first flood wave. Still, they did influence the vegetation on the gravel bars.

\section{Methods}

\section{Management measures}

Gravel bar I was completely removed in January 2009, and modelled subsequently from the extracted gravel as a mid-channel bar. During the May and June 2010 floods, this bar was buried under deposited gravel and changed 
into a point bar. The water management authority modified this bar in August 2010 by the partial removal of the upper layer and the deposition of the gravel on the remaining bar. Gravel bar II was completely removed in January/February 2010. During the May and June 2010 floods, it was overlaid by deposited gravel. Gravel bar III was completely removed in January 2010. During the May and June 2010 floods, it was overlaid by deposited gravel and divided into two parts. The upper part was bypassed by a lateral channel, and the lower part created a point bar. The water management authority further modified this bar in September 2010, by the partial removal of gravel in the upper part. Gravel bar IV was completely removed in January 2010, and was flooded during the May and June 2010 floods. A high degree of silting-up was recorded after these events. Gravel bar $V$ was completely removed in November 2009, and flooded during the May and June 2010 floods. Removal of gravel bar VI was planned for the beginning of 2010. Owing to some complications, only vegetation and a partial upper layer with gravel were removed by the water management authority in March 2010. The May 2010 flood removed more gravel from the upper layer. The bar started to be partly bypassed and was naturally divided into two parts: its lower part created a right point bar and the upper and middle parts created a mid-channel bar.

Field survey

Three permanent research plots of size $4 \times 4$ m were delimitated on each bar: in its proximal (p), central (c) and distal (d) parts (see Fig. 1). For these plots, ecological conditions such as shade, grain size, sediment siltation and elevation above sea level were surveyed. Shade was estimated with respect to surrounding tree cover, grain size and degree of siltation were based on granulometric analysis and elevation above sea level was determined using a GPS.

Phytosociological surveys were carried out on these plots in June 2009. A repeated phytosociological survey was undertaken in August 2010. Thanks to the May and June 2010 floods, it was not possible to keep the same term of the survey as in 2009. All species present were recorded and their abundance was assessed as percentage cover.

Data analysis

The vegetation data were processed in the program Turboveg for Windows 2.0 (Hennekens, Schaminée, 2001). The analyses were processed in Canoco for Windows (Ter Braak, Šmilauer, 2002; Lepš, Šmilauer, 2003), and Statistica (StatSoft, 2004). Level of the significance for all analyses and tests was set to $p=0.05$.

Results from relevés have been divided into four groups (see section Results). A modified classification algorithm Twinspan (Roleček et al., 2009) was used with the help of Sorensen's maximum degree of dissimilarity, three levels of pseudo-species with boundaries at $0 \%, 5 \%$ and $25 \%$, with four relevés as a minimum group size for further division.

The main gradients in vegetation composition were determined with the help of detrended correspondence analysis (DCA), for both species and relevés. DCA was also used to capture changes of the vegetation between 2009 and 2010. The size of the longest gradient, when using DCA, was 4.99. This finding led to the use of unimodal data analysis method. Untransformed data were used in the analyses. Ellenberg indication values (EIV), together with surveyed ecological conditions, were fitted passively into ordinance diagrams.

Mann-Whitney test was used for comparison of the number of species, Shannon-Wiener diversity index and EIV. This test was applied due to the small number of samples in the four groups.

\section{Results}

Four groups were distinguished on the basis of the phytosociological survey undertaken in June 2009. Their characteristics are described in Table 1.

In 2009, a total of 93 species were recorded on the permanent research plots. On average, 15 species occurred on each permanent research plot. On average, 9 species out of a total of 62 species, recorded by phytosociological relevés, were documented on each permanent research plot in 2010. In comparison to the relevés from 2009, i.e. before the removal of gravel bars, this was a significant decrease in the number of species. In 2010, the species composition of vegetation was considerably uniform. Annual, ruderal species dominated and also nitrophilous species played a significant role in the composition. 
$\mathrm{T}$ a b l e 1. Vegetation groups and their characteristics.

\begin{tabular}{|c|c|c|c|c|}
\hline Characteristics & Group 1 & Group 2 & Group 3 & Group 4 \\
\hline Short description & Initial vegetation stage & $\begin{array}{l}\text { Communities with } \\
\text { dominant Phalaris } \\
\text { arundinacea }\end{array}$ & $\begin{array}{l}\text { Higher proportion } \\
\text { of nitrophilous spe- } \\
\text { cies }\end{array}$ & $\begin{array}{l}\text { Highest successional } \\
\text { stage }\end{array}$ \\
\hline $\begin{array}{l}\text { Diagnostic } \\
\text { species }\end{array}$ & $\begin{array}{l}\text { Agrostis stolonifera, } \\
\text { Bidens frondosa, } \\
\text { Cardamine amara, } \\
\text { Persicaria maculosa, } \\
\text { Polygonum aviculare }\end{array}$ & $\begin{array}{l}\text { Salix fragilis, } \\
\text { Salix purpurea, } \\
\text { Calamagrostis } \\
\text { pseudophragmites }\end{array}$ & $\begin{array}{l}\text { Galium aparine, } \\
\text { Urtica dioica }\end{array}$ & $\begin{array}{l}\text { Salix purpurea, } \\
\text { Anthriscus sylvestris, } \\
\text { Cirsium oleraceum, } \\
\text { Festuca gigantea, } \\
\text { Geum urbanum, } \\
\text { Glechoma hederacea, } \\
\text { Chaerophyllum } \\
\text { hirsutum, } \\
\text { Scrophularia nodosa, } \\
\text { Solidago candensis, } \\
\text { Stachys sylvatica, } \\
\text { Symphytum } \\
\text { officinale, Valeriana } \\
\text { officinalis }\end{array}$ \\
\hline Constant species & $\begin{array}{l}\text { Impatiencs } \\
\text { glandulifera }\end{array}$ & P. arundinacea & $\begin{array}{l}\text { Impatiens glandu- } \\
\text { lifera, Impatiens } \\
\text { parviflora, P. arun- } \\
\text { dinacea }\end{array}$ & Galium aparine \\
\hline $\begin{array}{l}\text { Dominant } \\
\text { species }\end{array}$ & Not determined & P. arundinacea & $\begin{array}{l}\text { P. arundinacea, } U \text {. } \\
\text { dioica }\end{array}$ & Petasites albus \\
\hline Other features & $\begin{array}{l}\text { Initial stages } \\
\text { of annual and } \\
\text { nitrophilous species; } \\
\text { hemi-heliophytes; } \\
\text { small coverage }\end{array}$ & $\begin{array}{l}\text { Poor species } \\
\text { composition; } \\
\text { frequent Salix } \\
\text { purpurea in shrub } \\
\text { layer; relatively high } \\
\text { coverage }\end{array}$ & $\begin{array}{l}\text { Reed, meadow } \\
\text { and broad-leaved } \\
\text { nitrophilous species }\end{array}$ & $\begin{array}{l}\text { Higher number } \\
\text { of species; higher } \\
\text { diversity; shrubbery } \\
\text { and tree willows; } \\
\text { Alnus glutinosa }\end{array}$ \\
\hline
\end{tabular}

Relevés from 2010 were assigned to the 2009 groups according to found species.

Ordinance diagram (Fig. 2) displays data from all phytosociological relevés acquired in 2009. The first ordinance axis explains $15.8 \%$ of the total variability. We label it as the gradient of light. EIV for light, temperature and number of species show a significant relationship with the first axis. From the evaluated relevés, relevés from the group 1 - initial stages of vegetation on gravel bars - are situated on the far right of the gradient of light and include four relevés. The opposite side of the gradient is occupied by group 4 with three relevés, characterizing higher development stages of vegetation, with a higher number of species, less demanding light conditions and undemanding temperature. The middle part of the diagram is occupied by group 3 (six relevés), with a higher proportion of nitrophilous species, which is rather demanding on nutrients. Group 2 (five relevés), with dominant Phalaris arundinacea, is situated slightly to the right of group 3. Group 2 is characteristic of a low number of species and species preferring good light conditions. The second ordinance axis explains $6.2 \%$ of the total variability. It correlates weakly with EIV for moisture, and is represented by relevés with a higher proportion of species preferring moister conditions. Relevés with species more tolerant to moisture are situated in the upper part of the diagram. 


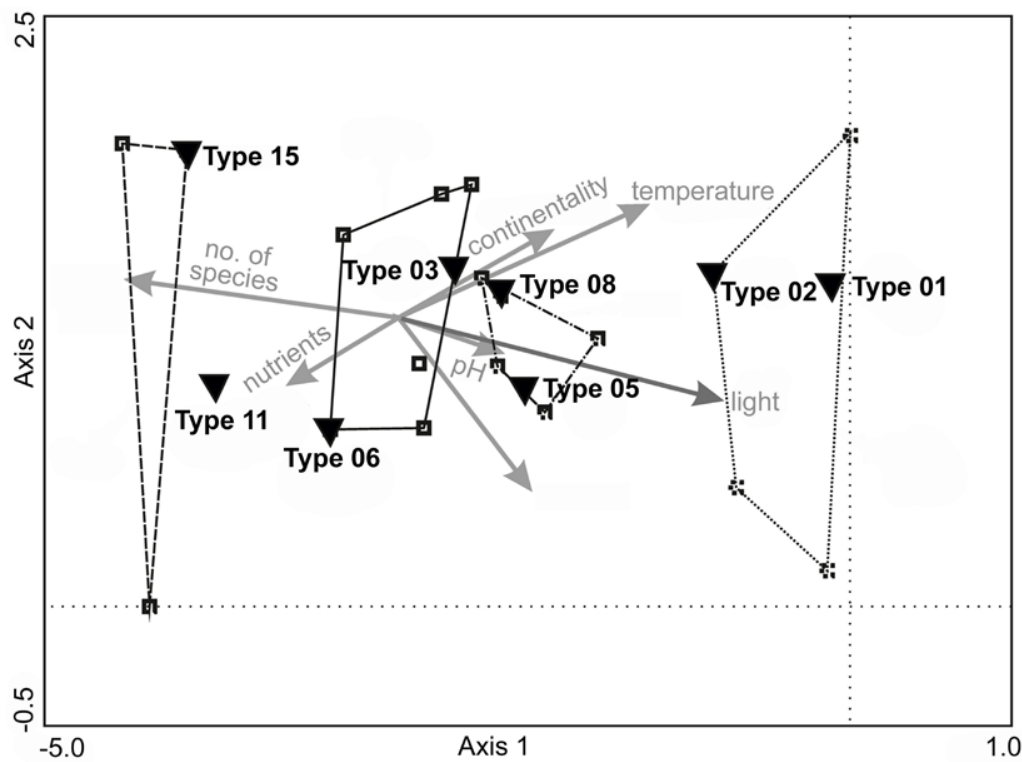

Fig. 2. DCA: ordinance diagram showing four vegetation groups (group 1 - dotted line, group 2 - dot-and-dash line, group 3 - full line, group 4 - dash line) and vegetation types (01-15) from 2009; the importance of EIV is represented by the arrow length and the angle that the arrow forms with each axis.

Individual vegetation types were fitted passively into the ordinance diagram. They are distributed along the first axis from right to left. The farthest right is occupied by vegetation type 01 (without vegetation or with sparse vegetation) and vegetation type 02 (sparse herbaceous vegetation). To the left, the vegetation types changes through monocoenoses and mosaics of $P$. arundinacea with shrubs. The farthest left is occupied by vegetation type 15 (tall shrub).

A statistical comparison of the number of species, Shannon-Wiener diversity index and average EIV from 2009 and 2010, without distinguishing groups, shows statistically significant differences in the number of found species, and average EIV for light, moisture and continentality. In groups 1 and 2, statistically significant differences were determined for moisture. A shift in the value of diversity index and EIV for light was recorded for group 3. No statistically significant differences in any variable were calculated for group 4 (Table 2).

The projection of relevés in the ordinance space, with the help of DCA (Fig. 3), shows noticeable variability suppression between relevés from 2009 and 2010 . The first ordinance axis explains $10.9 \%$ and the second axis $8.6 \%$ of the species variability. Relevés acquired in 2010 concentrate more to the left part of the diagram, and their position, in relation to the subvariables (number of species, diversity index and EIV), points to the species decline and diversity index decrease, as well as to the more pronounced emphasis on species demanding more light and temperature. A different trend was documented for relevé IVp from group 3 ; this relevé is situated in the central part of the diagram, where relevés from 2009, with Phalaris dominance, concentrate. Vegetation at the permanent research plot in 2010, from 
Table 2 p-Values of the Mann-Whitney test for comparison of the number of species, diversity index and EIV between 2009 and 2010.

\begin{tabular}{|l|c|c|c|c|c|}
\hline Variable & Total & Group 1 & Group 2 & Group 3 & Group 4 \\
\hline Number of species & $\mathbf{0 . 0 3 4}$ & 0.194 & 0.210 & 0.749 & 0.081 \\
\hline Diversity index & 0.569 & 0.149 & 0.676 & $\mathbf{0 . 0 4 5}$ & 1.000 \\
\hline Light & $\mathbf{0 . 0 2 9}$ & 0.885 & 0.676 & $\mathbf{0 . 0 0 5}$ & 0.081 \\
\hline Temperature & 0.887 & 0.470 & 0.917 & 0.810 & 0.081 \\
\hline Continentality & $\mathbf{0 . 0 2 9}$ & 0.470 & 0.060 & 0.749 & 0.383 \\
\hline Moisture & $\mathbf{0 . 0 0 3}$ & $\mathbf{0 . 0 3 0}$ & $\mathbf{0 . 0 1 2}$ & 0.936 & 1.000 \\
\hline Soil pH & 0.517 & 0.773 & 0.754 & 0.378 & 0.663 \\
\hline Nutrients & 0.155 & 0.112 & 0.095 & 0.873 & 1.000 \\
\hline
\end{tabular}

The values in bold represent statistically significant differences between the monitoring periods $(\mathrm{p}<0.05)$.

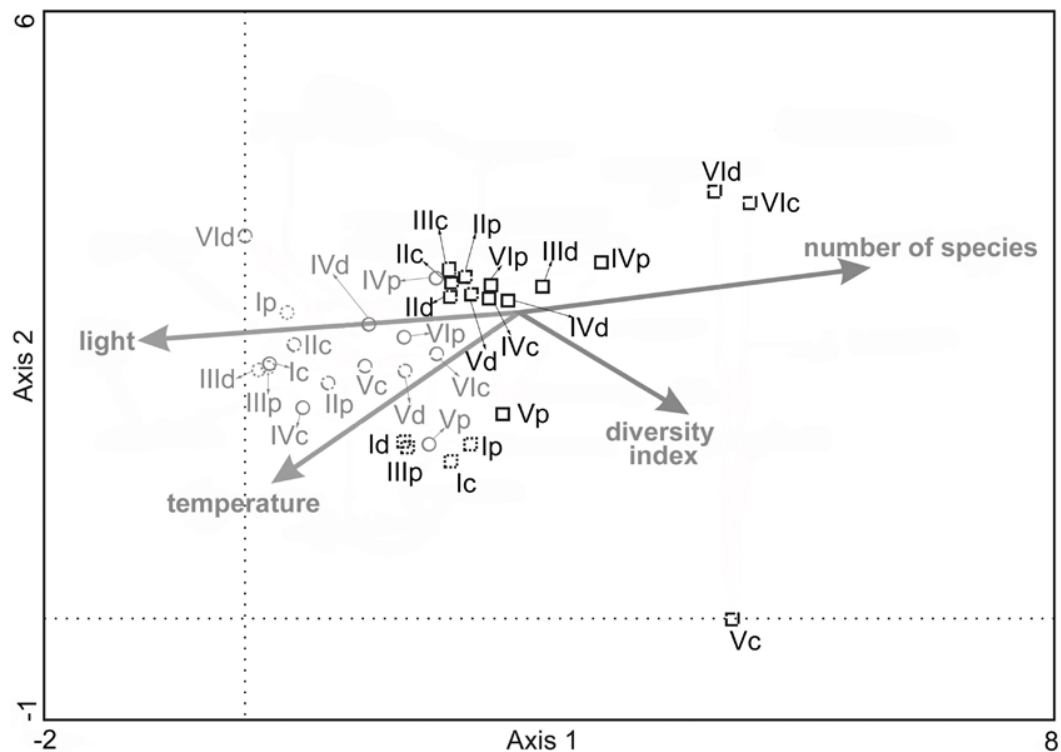

Fig. 3. DCA (ordination diagram) showing vegetation groups and relevés (labelled according to the bars I-VI, and location on the bar: $\mathrm{p}$ - proximal, $\mathrm{c}$ - central, $\mathrm{d}$ - distal part of the bar) from 2009 and 2010 (group 1 - dotted line, group 2 - dot-and-dash line, group 3 - full line, group 4 - dash line; relevés from 2009 are depicted in black as squares, relevés from 2010 in light grey as circles); the number of species, diversity index and EIV were used as supplementary variables. Only characteristics that are the most important in accordance with the species data are shown; the importance is displayed by the arrow length and angle of the axis.

which this relevé was captured, showed relatively high coverage, and the species composition corresponded to group 3 with the dominant $P$. arundinacea and presence of nitrophytes. The permanent research plot was influenced minimally by accomplished management, as the vegetation was not completely removed. The biotope was significantly silted-up. 


\section{Discussion and conclusion}

\section{Species occurrence and its reaction to floods and management measures}

Results from both vegetation survey and following analyses show a unilateral shift of vegetation on gravel bars in 2010, i.e. after management measures and floods, toward initial stages as is shown in Fig. 3 where 2010 relevés concentrate in the left part of the diagram, displaying increasing EIV for light and temperature. This shift was particularly pronounced for relevés from bars III, IV, V and VI that were covered by both herbaceous vegetation and shrubs in 2009 with less demand on light and temperature. Similar results were found after floods by Blažková (2003) or Klečka (2004).

Significant differences in the number of species on permanent research plots were expected between 2009 and 2010. This expectation was confirmed statistically (see Table 2). The main reason was combination of planned management, i.e. removal of gravel bars, together with vegetation cover, and unexpected floods during May and June 2010, which caused the deposition of material on bars and thus interrupted the succession. All these events resulted in the significant reduction of the species number as well as vegetation cover. These findings differed to some extent from Blažková (2003) who researched gravel bars on the Berounka River two months after floods and found small vegetation cover (like in our case) but quite high number of species, and also by Kollmann et al. (1999) on the Tagliamento River. Different findings from our investigation could be explained by three aspects: First, three permanent plots (Id, IId and IIIc) remained under water after the floods and thus no vegetation was found there. Second, the survey was undertaken in August 2010 and therefore represented summer aspect (compared to autumn aspect from Blažková, 2003) might play a role in the number of species. Third, additional management works at some bars were undertaken after floods and further inhibited succession (see section Management measures). This aspect seems to be the most significant one.

It can be assumed that number of species will increase in the following 1 or 2 years and then it will decrease again as was recorded in analogous sites by, e.g. Mikus et al. (2013) or Mouw et al. (2013).

Thanks to management works, the elevation of gravel bars was reduced which caused an increase of moisture and was reflected in vegetation composition from groups 1 and 2 where species with higher demands on moisture occurred, e.g. Veronica beccabunga, Agrostis stolonifera, Cardamine amara, Persicaria maculosa. Our findings correspond with Gilvear and Wilby (2006) who identified bar elevation as a key explanatory variable in species occurrence as it controls together with particle size the moisture regime of a patch.

Removal of vegetation cover influenced occurrence of species with high demands on light (e.g. Urtica dioica, Barbarea vulgaris, Poa compressa), especially from group 3. This was in accordance with the ecological demands of initial vegetation stages where moisture and light requirements together with its life form determine structure of the vegetation stand (Klečka, 2004; Grohmanová, 2012; Slavíková, 1986). 


\section{Management of biotopes on gravel bars}

Restoration of ecological processes, which enable the formation of gravel bars and other fluvial forms, where early successional habitats with higher diversity develop (Gilvear, Willby, 2006), might help flood protection by achieving a higher retention capacity in the upper reaches (Kollmann et al., 1999; Gilvear, Willby, 2006). On the other hand, the deposited fluvial material, in the form of gravel bars and subsequent vegetation islands, decreases the channel capacity to capture water from heavy rains and, therefore, is very often seen by a water management authority as one of the main causes of settlement flooding during extreme meteorological events. Thus, it is very difficult to find the right balance between flood protection of human settlements and the conservation of the unique biotopes bound to gravel bars, especially when they occur in or near settlements. An example of balancing human needs and environment protection is described in Church et al. (2001) and Piégay et al. (2006) for the Fraser River, where after a detailed geomorphological study sites for gravel extraction were selected. The extraction was designed to maintain the overall flux of sediment through the reach and stability of the bar system, and to mimic sedimentary features that create irregular bar edges (Piégay et al., 2006).

The proposed model management on gravel bars includes some irrelevant steps: namely the modelling of the surface of a remnant bar, because fluvial processes in the Ostravice, despite its regulation, approach natural behaviour. However, it might offer some solution for the management of gravel bars, providing that we accept continuous disturbance in the successional cycle, and thus the vegetation on these fluvial features never reaches its potential climax.

While there are works researching impact of such management on invertebrates or fish (Rempel, 2004), and there is quite an extensive literature about impact of river regulations on riparian vegetation along stream banks (e.g. Nilsson et al., 1991; Bernez et al., 2004; Biswas, Mallik, 2010), research of human disturbances on vegetation cover on gravel bars was conducted very rarely (e.g. Müller, 1998). Our research could therefore contribute to existing information on this topic in the scientific literature.

\section{Acknowledgements}

The research was supported by Czech Ministry of Environment (research project 'Monitoring of succession in localities chosen for gravel bars management') and Czech Ministry of Education, Youth and Sports (institutional support VUKOZ-IP-00027073).

\section{References}

Bernez, I., Daniel, H., Haury, J. \& Ferreira M.T. (2004). Combined effects of environmental factors and regulation on macrophyte vegetation along three rivers in Western France. River Research and Applications, 20, 43-59. DOI: $10.1002 /$ rra.718.

Birklen, P., Filipová, K., Klečka, J., Filipová, L. \& Lepík M. (2008). Gravel bed management on the Ostravice River (in Czech). Ochrana Př́rody, 6. http://www.casopis.ochranaprirody.cz/Pece-o-prirodu-a-krajinu/udrzba-sterkovych-lavic-na-rece-ostravici.html. Accessed 11 January 2012

Biswas, S.R. \& Mallik A.U. (2010). Disturbance effects on species diversity and functional diversity in riparian and upland plant communities. Ecology, 91, 28-35. DOI: 10.1890/08-0887.1. 
Blažková, D. (2003). Riverine vegetation of the Berounka River two months after flood in August 2002 (in Czech). Bohemia Centralis, 26, 35-44.

Bliss, L.C. \& Cantlon J.E. (1957). Succession on River Alluvium in Northern Alaska. Am. Midl. Nat., 58,452-469.

Buček, A. \& Štykar J. (2001). Geobiocoenological mapping in the Odra river watershed riparian zone of streams (in Czech). In Niva z multidisciplinárního pohledu (pp. 57-59). IV. Sborník abstraktů. Brno: Geotest.

Chuman, T., Lipský, Z. \& Matějček T. (2006). Succession of vegetation in alluvial floodplains after extreme floods. Sborník České Geografické Společnosti, 111, 314-325.

Church, M., Ham, D. \& Weatherly H. (2001). Gravel management in Lower Fraser River. Report prepared for the City of Chilliwack.

Chytrý, M., Kučera, T. \& Kočí M. (2001). Catalouge of biotopes of the Czech Republic (in Czech). Praha: AOPK ČR.

Edwards, P.J., Kollmann, J., Gurnell, A.M., Petts, G.E., Tockner, K. \& Ward J.V. (1999). A conceptual model of vegetation dynamics on gravel bars of a large Alpine river. Wetl. Ecol. Manag., 7, 141-153. DOI: 10.1023/A:1008411311774.

Gilvear, D. \& Willby N. (2006). Channel dynamics and geomorphic variability as controls on gravel bar vegetation; River Tummel, Scotland. River Research and Applications, 22, 457-474. DOI: 10.1002/rra.917.

Grohmanová, L. (2012). Succession and the development of alluvial communities after a flood in 1997. Journal of Landscape Ecology, 5, 29-49.

Gurnell, A.M., Petts, G.E., Hannah, D.M., Smith, B.P.G., Edwards, P.J., Kollmann, J., Ward, J.V. \& Tockner K. (2001). Riparian vegetation and island formation along the gravel-bed Fiume Tagliamento, Italy. Earth Surface Processes and Landforms, 26, 31-62. DOI: 10.1002/1096-9837(200101)26:1<31::AID-ESP155>3.0.CO.

Hennekens, S.M. \& Schaminée J.H.J. (2001). TURBOVEG, a comprehensive data base management system for vegetation data. J. Veg. Sci., 12, 589-591. DOI: 10.2307/3237010.

Hrádek, M. (2004). Floods and human impacts to braided river patterns in the Western Carpathians foothill. In D. Drbohlav, J. Kalvoda \& V. Voženílek (Eds.), Czech geography at the dawn of the millennium (pp. 137-149). Olomouc: Univerzita Palackého.

Hupp, C.R. \& Osterkamp W.R. (1985). Bottomland vegetation distribution along Passage Creek, Virginia, in relation to fluvial landforms. Ecology, 66, 670-681. DOI: 10.2307/1940528.

Jeník, J. (1955). Vegetation succession on the Belá gravel bars (in Czech). Praha: Nakladatelství Karlovy Univerzity

Kalníková, V. (2009). Distribution of invasive neophytes along the Ostravice and Morávka Rivers (in Czech). Diplomová práce. Brno: Masarykova univerzita.

Klečka, J. (2004). Early stadiums of floodplain forest succession in a wide river beds upon and example of Bečva. J. For. Sci. (Prague), 50, 338-352.

Kollmann, J., Vieli, M., Edwards, P.J., Tockner, K. \& Ward J.V. (1999). Interactions between vegetation development and island formation in the Alpine river Tagliamento. Appl. Veg. Sci., 2, 25-36. DOI: 10.2307/1478878.

Kopecký, K. (1957). Vegetation succession on bars of the Metuje and Olešenka rivers in the surroundings of Nové Město nad Metují (in Czech). Preslia, 29, 51-63.

Lepš, J. \& Šmilauer P. (2003). Multivariate analysis of ecological data using CANOCO. Cambridge: Cambridge University Press.

Loučková, B. (2012). Vegetation-landform assemblages along selected rivers in the Czech Republic, a decade after a 500-year flood event. River Research and Applications, 28, 1275-1288. DOI: 10.1002/rra.1519.

Mikus, P., Wyzga, B., Kaczka, R.J., Walusiak, E. \& Zawiejska J. (2013). Islands in a European mountain river: Linkages with large wood deposition, flood flows and plant diversity. Geomorphology, 202, 115-127. DOI: 10.1016/j. geomorph.2012.09.016.

Moravec, J., Balátová-Tuláčková, E., Blažková, D., Hadač, E., Hejný, S., Husák, Š., Jeník, J., Kolbek, J., Krahulec, F., Kropáč, Z., Neuhäusl, R., Rybníček, K., Řehořek, V. \& Vicherek J. (1995). Plant communities of the Czech Republic and their endangerment (in Czech). Litoměřice: Okresní vlastivědné museum.

Mouw, J.E.B., Chaffin, J.L., Whited, D.C., Hauer, F.R., Matson, P.L. \& Stanford A. (2013). Recruitment and successional dynamics diversify the shifting habitat mosaic of an Alaskan floodplain. River Research and Applications, 29(6), 671-685. DOI: 10.1002/rra.2569.

Müller, N. (1998). Effects of natural and human disturbances on floodplain vegetation. In N. Müller, S. Okuda \& N. Tama (Eds.), Proceedings of the International Symposium for River Restoration (pp. 15-24). Tokyo.

Neuhäuslová, Z., Blažková, D., Grulich, V., Husová, M., Chytrý, M., Jeník, J., Jirásek, J., Kolbek, J., Kropáč, Z., Ložek, V., Moravec, J., Prach, K., Rybníček, K., Rybníčková, E. \& Sádlo J. (2001). Map of potential natural vegetation of the Czech Republic (in Czech). Praha: Academia. 
Nilsson, C., Ekblad, A., Gardfjell, M. \& Carlberg B. (1991). Long-term effects of river regulation on river margin vegetation. J. App. Ecol., 28, 963-987. DOI: 10.2307/2404220.

Piégay, H., Grant, G., Nakamura, F. \& Trustrum N. (2006). Braided river management: from assessment of river behaviour to improved sustainable development. In G. Sambrook Smith, J. Best, C. Bristow \& G. Pets (Eds.), Braided rivers: processes, deposits, ecology and management. No. 36. Oxford: Blackwell Publishing Ltd.

Prach, K. (1994). Vegetation succession on river gravel bars across the north western Himalayas, India. Arct. Alp. Res., 26, 349-353.

Rempel, L.L. (2004). Physical and ecological organization in a large, gravel-bed river and response to disturbance. $\mathrm{PhD}$ thesis, University of British Columbia,

Richards, K., Brasington, J. \& Hughes F. (2002). Geomorphic dynamics of floodplains: ecological implications and a potential modelling strategy. Freshw. Biol., 47, 559-579. DOI: 10.1046/j.1365-2427.2002.00920.x.

Roleček, J., Tichý, L., Zelený, D. \& Chytrý M. (2009). Modified TWINSPAN classification in which the hierarchy respects cluster heterogeneity. J. Veg. Sci., 20, 596-602. DOI: 10.1111/j.1654-1103.2009.01062.x.

Sandev, M., Valeriánová, A., Šercl, P., Čekal, R., Kocman, T., Tureček, B., Šikula, J., Brtníková, H. \& Štěpánková P. (2011). Evaluation of floods from May and June 2010 (in Czech). Souhrnná zpráva. Praha: VÚV TGM.

Slavíková, J. (1986). Plant ecology (in Czech). Praha: SPN.

StatSoft Inc. (2004). STATISTICA Cz, version 10.0. Available from www.statsoft.cz.

Ter Braak, C.J.F. \& Šmilauer P. (2002). CANOCO Reference manual and CanoDraw for Windows user's guide: software for canonical community ordination (version 4.5). Ithaca: Microcomputer Power.

Tockner, K., Ward, J.V., Arscott, D.B., Edwards, P.J., Kollmann, J., Gurnell, A.M., Petts, G.E. \& Maiolini B. (2003). The Tagliamento River: A model ecosystem of European importance. Aquatic Sciences, 65, 239-253. DOI: 10.1007/ s00027-003-0699-9.

Weissmannová, H., Barciuchová, K., Bartošová, D., Beneš, B., Bureš, L., Buzek, L., Demek, J., Džubera, P., Foral, M., Hájková, A., Holec, J., Holuša, O., Hrabovský, S., Hudec, K., Chytil, P., Ihnatíková, L., Jaskula, F., Kališsová, Š., Kneblová, I., Koutecká, V., Kříž, V., Laštůvka, Z., Lustyk, P., Machačová, J., Myslikovjan, T., Mračanská, E., Nesládková, L., Neuschlová, Š., Otáhal, I., Petřvaldský, J., Popelář, P., Prymusová, Z., Roháček, J., Roháčová, M., Sedláčková, M., Štanovský, J., Svatuška, M., Šafáŕ, J., Škrott, M., Šulgan, F., Tomanová, D. \& Wolfová J. (2004): Ostrava Region (in Czech). In P. Mackovčin \& M. Sedláček (Eds.), Chráněná území ČR. Svazek X. Brno, Praha: AOPK ČR a EkoCentrum. 